\title{
Bias accusation rattles US biosecurity board
}

\author{
Case for full publication of controversial flu studies was unbalanced, board member says.
}

\section{Brendan Maher}

14 April 2012

The closed meeting convened last month by the US government to decide the fate of two controversial papers on the H5N1 avian influenza virus was stacked in favour of their full publication, a participant now says. Michael Osterholm, who heads the University of Minnesota's Center for Infectious Disease Research and Policy in Minneapolis, is a member of the National Science Advisory Board for Biosecurity (NSABB), which was tasked with evaluating the research. In a letter to Amy Patterson, associate director for science policy at the National Institutes of Health (NIH) in Bethesda, Maryland, and sent to other members of the NSABB, Osterholm writes that the meeting agenda and presenters were "designed to produce the outcome that occurred". The letter was leaked to Nature by an anonymous source.

The two-day meeting held at the end of March was meant to put an end to the controversy swirling around research papers describing an H5N1 avian influenza virus that is transmissible between mammals - in this case ferrets, which are a model for human flu transmission. When the US government asked the NSABB in autumn of 2011 to review the papers for publication, the board suggested that the papers be published in redacted form, stripped of details that would allow people to recreate the viruses.

The recommendation was a controversial compromise, pitting the ideals of open, international science communication against concerns that the work could be misused by bioterrorists or result in the accidental release of a potentially devastating pathogen. In February, after the World Health Organization convened a brief meeting in Geneva, Switzerland, that favoured full publication, the US government asked the NSABB to reconvene and reconsider its position in light of modifications made to the papers and new information presented by the researchers.

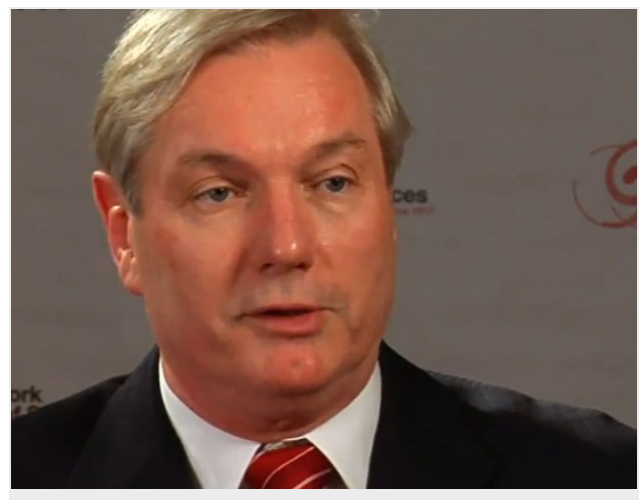

Michael Osterholm appeared in this Nature video explaining the mutant H5N1 controversy in February.

At that meeting, the NSABB revised its position, voting unanimously to publish one of the papers, a manuscript submitted to Nature by Yoshihiro Kawaoka of the University of Wisconsin, Madison, and the University of Tokyo. But the board voted only 12-6 in favour of publishing the other paper, submitted to Science by Ron Fouchier of the Erasmus Medical Center in Rotterdam, the Netherlands. Several members of the board, including Osterholm, felt that the modifications made to the paper did not strip away their concerns.

In the letter, dated 12 April, Osterholm writes that the March meeting was stacked heavily in favour of experts who do similar research on flu viruses and who had an interest in the outcome of the decision. It did not give voice to disinterested scientists with relevant expertise. He says that he had recommended several such individuals and that they were not invited. Although arguments were made at the meeting that the data in these papers would support surveillance efforts, Osterholm said that there were no experts working on the frontlines of influenza surveillance present. A recent analysis by Nature suggested that surveillance efforts require other kinds of support before they could use such data. And a security briefing that Osterholm says influenced many of the NSABB members was, he writes, "one of them [sic] most incomplete and, dare I say, useless classified security briefings l've ever attended". Osterholm has worked on biosecurity issues for the US Department of Health and Human Services for the past 20 years.

Before the meeting, assessments deemed the NSABB's proposed redactions too difficult to facilitate. The NSABB had recommended that only brief announcements of the findings be published and that only qualified, vetted experts be allowed access to the full data and methods.

Officials essentially took that option off the table, meaning that NSABB members would have to vote either for full publication or no publication. Osterholm writes that this all-or-nothing approach merely "kicked the can down the road", saying that he heard at the meeting that Fouchier has found "one additional mutation that now confers H5N1 transmissibility between mammals without ferret passage". Publishing this finding could raise the same issues: "If we believe redaction of the current manuscript is problematic in terms 
of international agreements, I think the next mutation paper will prove to be the straw that breaks the camel's back."

Osterholm, when contacted by phone, would say little about the letter, which he did not make public. He asserted that "this type of review must be based on an expert, scientific, risk-benefit basis. And it should involve disinterested experts from a variety of fields." He also noted: "I have been and continue to be a supporter of this kind of research."

At publication of this story, neither Patterson nor other officials at the $\mathrm{NHH}$ were able to respond.

Nature | doi:10.1038/nature.2012.10454

\section{Supplementary information}

\section{Word documents}

1. Osterholm letter (201K)

Osterholm letter 